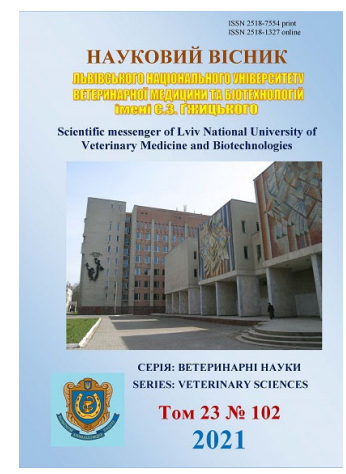

Науковий вісник Аьвівського національного університету ветеринарної медицини та біотехнологій імені С.3. Гжицького. Серія: Ветеринарні науки

\author{
Scientific Messenger of Lviv National University \\ of Veterinary Medicine and Biotechnologies. \\ Series: Veterinary sciences
}

doi: $10.32718 /$ nvlvet10204 https://nvlvet.com.ua/index.php/journal

UDC 577.352.315:612.33

\title{
Changes in the structural components of the mucous membrane and plasma proteins of small intestine enterocytes in fetuses of cattle
}

D. M. Masiuk

Dnipro state agrarian and economic university, Dnipro, Ukraine

Article info

Received 01.03.2021

Received in revised form 01.04 .2021

Accepted 02.04.2021

Dnipro State Agrarian and Economic University, Serhiya Yefremova Str., 25, Dnipro, 49000, Ukraine.

Tel.: +38-050-636-62-37

E-mail:dimasiuk@gmail.com
Masiuk, D. M. (2021). Changes in the structural components of the mucous membrane and plasma proteins of small intestine enterocytes in fetuses of cattle. Scientific Messenger of Lviv National University of Veterinary Medicine and Biotechnologies. Series: Veterinary sciences, 23(102), 24 28. doi: $10.32718 /$ nvlvet10204

The interrelationships of morphological changes of the mucosa of the large intestine with the dynamics of enzyme activity at different poles of enterocytes of cattle during the fetal period of ontogenesis are shown and analyzed. The work was performed on Holstein cattle aged two to nine months. The activity of hydrolytic and transport enzymatic systems in the basolateral membrane of cattle enterocytes depends less on the morphometric parameters of the large intestine than in the apical membrane. It is proved that during the fruitful period of ontogenesis there are dynamic transformations of enzyme systems of enterocytes of the large intestine of cattle which are connected with morphological changes of the mucous membrane of the large intestine. The activity of hydrolytic and transport enzymes in different domains of the plasma enterocytes of fetal cattle is interrelated with the morphometric parameters of the colon, in particular. the activity of alkaline phosphatase, $\gamma$-glutamyltransferase, $\mathrm{Na}^{+}, \mathrm{K}^{+}$-ATPase, $\mathrm{Ca}^{2+}, \mathrm{Mg}^{2+}$-ATPase and Mg-ATPase in the apical membrane of enterocytes is inversely related to the thickness of the intestinal wall with villi and the mucous membrane of the cavity $(P \leq 0.01-0.001)$. A significant correlation was found between the activity of alkaline phosphatase, $\gamma$-glutamyltransferase, $\mathrm{Na}^{+}, \mathrm{K}^{+}$-ATPase, $\mathrm{Ca}^{2}{ }^{+}, \mathrm{Mg}^{2+}$-ATPase and $\mathrm{Mg}$ ATPase in the apical membrane of enterocytes with villi height $(P \leq 0.05)$. The activity of hydrolytic and transport enzymatic systems in the basolateral membrane of bovine fetal enterocytes depends to a lesser extent on the morphometric parameters of the large intestine than in the apical membrane. In particular, only the activity of alkaline phosphatase and $\gamma$-glutamyltransferase is inversely related to the thickness of the intestinal wall with villi and the mucous membrane of the jejunum with villi $(P \leq 0.01-0.001)$. The activity of transport enzymes is directly related to the morphometric parameters of the colon $(P \leq 0.01)$. The activity of these enzymes in the basolateral membrane does not significantly depend on the width of the villi, but is dependent on their height.

Key words: fetus, cattle, enterocytes, small intestine, enzymes.

\section{Зміни структурних компонентів слизової оболонки та протеїнів плазмолеми ентероцитів порожньої кишки плодів великої рогатої худоби}

\author{
Д. М. Масюк \\ Дніпровський державний аграрно-економічний університет, м. Дніпро, Украӥна
}

\footnotetext{
Показано і проаналізовано взаємозв'язки морфологічних змін слизової оболонки порожньої кишки з динамікою активності ензимів на різних полюсах ентероцитів великої рогатої худоби протягом плодового періоду онтогенезу. Роботу виконано на плодах великої рогатої худоби Голштинської породи, віком від двох до дев'яти місяців. Активність гідролітичних і транспортних ензиматичних систем у базолатеральній мембрані ентероцитів плодів великої рогатої худоби у меншій мірі залежить від морфометричних показників порожньої кишки, ніж така в апікальній мембрані. Доведено, шуо протягом плодового періоду онтогенезу відбуваються динамічні перетворення ферментних систем ентерочитів порожньої кишки великої рогатої худоби щзо пов'язані з мор-
} 
фологічними змінами слизової оболонки порожньої кишки. Активність гідролітичних і транспортних ензимів у різних доменах плазмолеми ентероцитів плодів великої рогатої худоби взаємопов'язана з морфометричними показниками порожньої кишки,

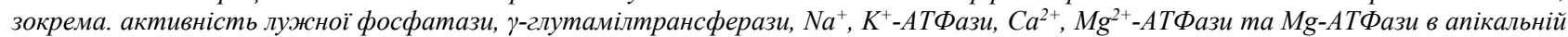
мембрані ентероцитів обернено пов'язана з товщиною кишкової стінки з ворсинками та слизової оболонки порожньої кишки з ворсинками $(P \leq 0,01-0,001)$. Встановлено достовірний кореляційний зв'язок активності лужної фосфатази, $\gamma$ -

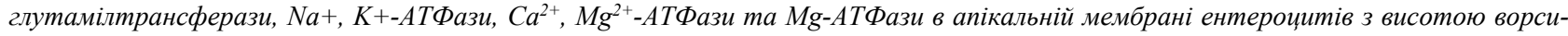
нок $(P \leq 0,05)$. Активність гідролітичних і транспортних ензиматичних систем у базолатеральній мембрані ентероцитів плодів великої рогатої худоби у меншій мірі залежить від морфометричних показників порожньої кишки, ніж така в апікальній мембрані. Зокрема, лише активність лужної фосфатази та ү-глутамілтрансферази обернено пов'язана з товщиною кишкової стінки з ворсинками та слизової оболонки порожньої кишки з ворсинками $(P \leq 0,01-0,001)$. Активність транспортних ензимів має прямі зв'язки з морфометричними показниками порожньої кишки $(P \leq 0,01)$. Активність цих ензимів у базолатеральній мембрані достовірно не залежить від ширини самих ворсинок, однак $є$ залежною від їх висоти.

Ключові слова: плід, велика рогата худоба, ентерочити, порожня кишка, ензими.

\section{Вступ}

Протягом плодового періоду підвищуються функціональні можливості секреторного, моторного і абсорбційного апаратів травного тракту та ензимних систем тонкої кишки (Zhang et al., 2020). Відбувається підготовка травного апарату до постнатального лактотрофного живлення. Розвиток епітелію тонкої кишки у плодів і телят на ранньому постнатальному етапі розвитку підпорядкований загальним для тканин закономірностям. Відомо, що під час внутрішньоутробного розвитку моторика травного тракту та секреція його залоз слабко розвинені і регулюються місцевими механізмами (Woods et al., 2018; Masiuk, 2020). Якщо на перших етапах ембріонального розвитку стравохід і тонка кишка мають місця тимчасової закупорки, то надалі травний тракт стає прохідним і має слабкі перистальтичні рухи, чим переміщує у нижні відділи меконій (Lisowska-Myjak et al., 2018). До його вмісту входить секрет шлунку і кишечника, щільні частини, що містяться в навколоплодних водах, епітелій шкіри плода тощо. Склад ензимів, їх локалізація і активність у тонкій кишці обумовлені в ембріогенезі закладкою та формуванням внутрішньоклітинного, мембранного і порожнинного типів травлення. 3 другого триместру життя плода великої рогатої худоби було виявлено виражену активність травних ензимів у сичузі (Guilloteau et al., 1984).

Плазматична мембрана епітелію клітини поділяється на два основні домени. Апікальна поверхня стикається 3 просвітом органу, а базолатеральна поверхня - з сусідніми епітеліальними клітинами. Апікальні та базолатеральні поверхні ентероцитів виконують не однакові функції і тому мають дуже різні білкові та ліпідні композиції. Апікальна поверхня спеціалізується на обміні субстратів із порожниною, тоді як базолатеральна поверхня взаємодії з іншими клітинами і кров'яним руслом (Johnston \& Sanson, 2011). Плазматична мембрана ентероцитів тонкого кишечника містить багато специфічних гідролаз (Kenny \& Maroux, 1982). У плода великої рогатої худоби розподіл кишкових ензимів у всьому травному тракту неоднорідний.

Онтогенетичні особливості активності ензимів тонкого кишечника на різних стадіях розвитку плодів мишей $є$ досить добре вивченими, однак залишаються нез'ясованими взаємозв'язки морфологічних змін слизової оболонки порожньої кишки 3 динамікою активності ензимів мембран ентероцитів великої рогатої худоби у плодовому періоді онтогенезу.

\section{Матеріал і методи досліджень}

Дослід проведено на 80 плодах великої рогатої худоби Голштинської породи, віком від двох до дев'яти місяців, з масою тіла від 0,6 до 39 кг. Плоди були отримані від клінічно здорових корів, під час вимушеного забою. Вік плодів встановлювали за методом, описаним Студенцовим А. П. Для морфологічних досліджень шляхом анатомічного препарування відбирали зразки тканин порожньої кишки. Для отримання оглядових препаратів, проведення морфометричних досліджень фрагменти тканин заливали у парафін за загальноприйнятою методикою. Із парафінових блоків на санному та ротаційному мікротомах готували тотальні гістозрізи. Дослідження гістологічних препаратів проводили за допомогою стереоскопічного мікроскопа МБС-10 і світлових Olimpus $\mathrm{CH}-20$, CX-41. Кількісний (морфометричний) аналіз тканинних компонентів проводили за методикою “крапкового підрахунку" з використанням окулярних тестових систем (вставок) із 256 рівновіддаленими крапками за Автанділовим. Диференційний підрахунок крапок здійснювали за допомогою лабораторного лічильника. Підрахунок крапок і вимірювання на МБС-10 проводили за збільшення $8 \times 2 ; 8 \times 4 ; 8 \times 7$, а на світлових мікроскопах - окуляр $10 \times$, об'єктив 4/;10/;40/. За основу виділення кишкових клітин був хімічний (цитрат/ЄДТО) метод (Tomchuk et al., 1994) на основі якого розроблялась авторська модифікація методу (Патент на корисну модель № 118136 Україна. Спосіб одержання ізольованих ентероцитів плодів великої рогатої худоби) отримання ізольованих ентероцитів порожньої кишки плодів великої рогатої худоби. Якість отриманих епітеліальних клітин оцінювали за морфологічними i функціональними показниками. Для отримання апікальних і базолатеральних мембран із суспензії ізольованих ентероцитів порожньої кишки плодів великої рогатої худоби використовували базову методику диференціального центрифугування (Tsvilikhovskiy, 1989) у нашій модифікації (Патент на корисну модель № 118133 Спосіб фракціонування плазматичних мембран ізольованих ентероцитів). В апікальних і базолатеральних мембранах визначали активність лужної фосфатази (КФ 3.1.3.1.) за методом Гарена-Левенталя, $\gamma$-глутамілтрансферази $\quad$ (КФ 


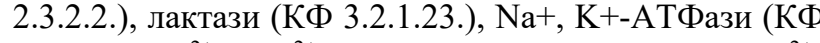
3.6.3.9), $\mathrm{Ca}^{2+}, \mathrm{Mg}^{2+}$-АТФази (КФ 3.6.1.3) та $\mathrm{Mg}^{2+}$ АТФази (КФ 3.6.3.2) згідно рекомендацій Болдирєва (Boldyrev, 1977). Гідроліз аденозинтрифосфату препаратами мембран реєстрували у незабуференому середовищі рН-метрично. Інкубаційне середовище для дослідження АТФаз мало наступний склад, мМ: 100 $\mathrm{NaCl}, 250$ сахарози, $5 \mathrm{MgCl}_{2}, 2,5 \mathrm{ATP}, 0,5 \mathrm{CaCl}_{2}, 40$ (для апікальної мембрани) та 20 (для базолатеральної мембрани) теофілліна; склад мембран - 50 мкг білку

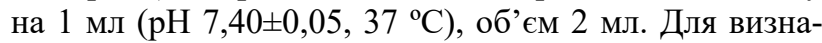
чення $\mathrm{Na}^{+}, \mathrm{K}^{+}$-АТФази в середовище додатково вносили $20 \mathrm{MM} \mathrm{KCl}$, а вміст $\mathrm{NaCl}$ підвищували до 120 мМ; до середовища також додавали 1 мМ уабаіна. Для дослідження $\mathrm{Ca}^{2+}, \mathrm{Mg}^{2+}$-АТФази до дослідної проби додатково додавали 0,5 мМ ЕГТО, при цьому $\mathrm{Ca}^{2+}$ не вносили. Для визначення $\mathrm{Mg}^{2+}-\mathrm{AТФази} \mathrm{у} \mathrm{про-}$ бах додатково були присутні $0,5 \mathrm{MM} \mathrm{ЕГТО} \mathrm{та} 1 \mathrm{MM}$ уабаіну, при цьому $\mathrm{Ca}^{2+}$ не додавали; у дослідну пробу не вносили $\mathrm{MgCl}_{2}$. Кожну експериментальну криву калібрували наприкінці досліду неорганічним фосфатом $\left(\mathrm{KH}_{2} \mathrm{PO}_{4}\right)$. Відносну активність розраховували по різниці активності контрольної та дослідної проб.

Експериментальні дослідження проведені із дотримання вимог Закону України № 3447 - IV від 21.02 .06 р. "Про захист тварин від жорстокого поводження" та узгоджуються 3 основними принципами “Європейської конвенції з захисту хребетних тварин, що використовуються для експериментальних та наукових цілей” (Страсбург, 1986), декларації “Про гуманне ставлення до тварин” (Гельсінкі, 2000) і Національного конгресу з біоетики “Загальні етичні принципи експериментів на тваринах” (Київ, 2001).

Одержані цифрові дані опрацьовували статистично. Коефіцієнт кореляції (r) розраховувалися методом Пірсона за допомогою прикладного програмного комплексу "Microsoft Office Excel 2016".

\section{Результати та їх обговорення}

Встановлено, що розвиток слизової оболонки порожньої кишки у плодів великої рогатої худоби характеризується біологічними ритмами періодичності у 2-3 місяця, які відображають іiї як структурні так i функціональні зміни. Вікові зміни морфології слизової оболонки порожньої кишки у плодоому періоді онтогенезу супроводжуються поступовим збільшенням іiі складчастості, розвитку ворсин, зростанням їх довжині і кількості, формуванні м'язової пластинки слизової, що чітко виявляється у шестимісячних плодів.

Дослідженнями встановлено, що активність транспортних АТФаз плазматичної мембрани ентероцитів порожньої кишки великої рогатої худоби протягом раннього плодового періоду поступово знижується на обох морфо-функціональних ділянках плазмолеми при більш високій активності цих ензимів на базолатеральній мембрані. Пік активності цих ензимів на базолатеральному домені плазматичної мембрани ентероцитів порожньої кишки припадає на сьомий місяць внутрішньоутробного розвитку. В цей час їх активність більша у $2-2,5$ раза $(\mathrm{P}<0,001)$ відповідно до такої у плодів віком шість місяців, після чого вона до кінця плодового періоду знижується на 15-41 \% $(\mathrm{P}<0,05-0,001)$. На противагу цьому активність АТФаз на апікальному полюсі 3 п'яти - до дев'ятимісячного віку поступово зменшується у 1,52,2 раза (Р < 0,001). Слід відмітити, що динаміка активності гідролітичних ензимів плазмолеми ентероцитів порожньої кишки впродовж плодового періоду більш варіабельна ніж транспортних. Так, активність лужної фосфатази на апікальному та базолатеральному полюсі клітин зменшується у 9 раз $(\mathrm{P}<0,001)$ та 3,8 рази $(\mathrm{P}<0,001)$ відповідно. Зазначимо більшу активність цього ензиму на базолатеральному домені. Активність гаммаглутамілтрансферази на апікальному полюсі клітин зменшується у 1,92 рази $(\mathrm{P}<0,001)$, а на базолатеральному у 6,59 рази $(\mathrm{P}<0,001)$ з перерозподілом полярної активності з базальної на апікальну мембрану в восьмимісячному віці. Цікаво зауважити, що активність лактази на обох доменах ентероцитів до П'ятимісячного віку плодів збільшується у $1,5-1,9$ рази $(\mathrm{P}<0,001)$ після чого до кінця плодового періоду зменшується відповідно у 2-4,8 рази ( $<<0,001)$ з постійним переважанням полярної активності на апікальній мембрані.

Проведені дослідження свідчать, що активність гідролітичних і транспортних ензимів у різних доменах плазмолеми ентероцитів плодів великої рогатої худоби взаємопов'язана 3 морфометричними показниками порожньої кишки (табл. 1). Так, активність лужної фосфатази, $\gamma$-глутамілтрансферази, $\mathrm{Na}^{+}, \mathrm{K}^{+}$-АТФази, $\mathrm{Ca}^{2+}, \mathrm{Mg}^{2+}$-АТФази та $\mathrm{Mg}$-АТФази в апікальній мембрані ентероцитів обернено пов'язана 3 товщиною кишкової стінки з ворсинками та слизової оболонки порожньої кишки 3 ворсинками (r=-0,86-0,97; $\mathrm{P} \leq 0,01-0,001)$. Важливо відзначити, що від $74 \%$ до $94 \%$ (P $\leq 0,01-0,001)$ варіацій активності цих ензимів на апікальному домені плазмолеми ентероцитів залежить від товщини кишкової стінки $з$ ворсинками та слизової оболонки порожньої кишки 3 ворсинками плодів великої рогатої худоби. Крім цього, активність вказаних ензимів достовірно не залежить від ширини самих ворсинок, однак є обернено залежною від їх висоти. Так, кореляційний зв'язок активності лужної фосфатази, $\gamma$-глутамілтрансферази, $\mathrm{Na}^{+}, \mathrm{K}^{+}$-АТФази, $\mathrm{Ca}^{2+}, \mathrm{Mg}^{2+}$-АТФази та $\mathrm{Mg}$-АТФази в апікальній мембрані ентероцитів 3 висотою ворсинок становив $r=-0,89 \quad(P \leq 0,01), r=-0,91 \quad(P \leq 0,01), r=-0,89$ $(\mathrm{P} \leq 0,01), \mathrm{r}=-0,80(\mathrm{P} \leq 0,05)$ та $\mathrm{r}=-0,77(\mathrm{P} \leq 0,05)$. Аналіз коефіцієнту детермінації вказує, що відповідно, від $59 \%$ до $83 \%$ (Р $\leq 0,05-0,01)$ варіацій активності цих ензимів на апікальному домені плазмолеми ентероцитів залежить від висоти ворсинок порожньої кишки плодів великої рогатої худоби. 


\section{Таблиця 1}

Взаємозв'язок (r) морфометричних змін основних структурних компонентів слизової оболонки порожньої кишки плодів великої рогатої худоби з активністю ензимів на різних полюсах плазмолеми ентероцитів

\begin{tabular}{|c|c|c|c|c|c|c|c|c|}
\hline \multirow{4}{*}{ Ензими } & \multicolumn{8}{|c|}{ Порожня кишка плодів великої рогатої худоби } \\
\hline & \multicolumn{4}{|c|}{ Слизова оболонка } & \multicolumn{4}{|c|}{ Показники ворсинок } \\
\hline & \multicolumn{2}{|c|}{$\begin{array}{c}\text { Кишкова стінка } 3 \\
\text { ворсинками } \\
\end{array}$} & \multicolumn{2}{|c|}{$\begin{array}{c}\text { Слизова оболонка } 3 \\
\text { ворсинками }\end{array}$} & \multicolumn{2}{|c|}{ Висота } & \multicolumn{2}{|c|}{ Ширина } \\
\hline & $\mathrm{AM}$ & БM & AM & БM & AM & БM & AM & БM \\
\hline \multicolumn{9}{|c|}{ Апікальна мембрана } \\
\hline ALP & $-0,86 * *$ & $-0,82 *$ & $-0,86 * *$ & $-0,83 *$ & $-0,89 * *$ & $0,81 * *$ & 0,62 & 0,41 \\
\hline GGT & $-0,91 * *$ & $-0,98 * * *$ & $-0,91 * *$ & $-0,97 * * *$ & $-0,91 * *$ & $0,74 * *$ & 0,67 & 0,42 \\
\hline Лактаза & $-0,63$ & $-0,41$ & $-0,55$ & $-0,39$ & $-0,12$ & 0,00 & 0,02 & 0,02 \\
\hline $\mathrm{Na}^{+}, \mathrm{K}^{+}$-АТФаза & $-0,95 * * *$ & $0,74^{*}$ & $-0,92 * *$ & 0,66 & $-0,89 * *$ & 0,26 & 0,69 & 0,13 \\
\hline $\mathrm{Ca}^{2+}, \mathrm{Mg}^{2+}-\mathrm{AТФаза}$ & $-0,97 * * *$ & 0,63 & $-0,93 * *$ & 0,52 & $-0,80^{*}$ & 0,05 & 0,59 & 0,02 \\
\hline Мg-АТФаза & $-0,97 * * *$ & $0,84 * *$ & $-0,93 * *$ & $0,76^{*}$ & $-0,77^{*}$ & 0,29 & 0,56 & 0,14 \\
\hline
\end{tabular}

Примітки: *-P $\leq 0,05 ; * *-\mathrm{P} \leq 0,01 ; * * *-\mathrm{P} \leq 0,001$

Слід відмітити, що активність гідролітичних і транспортних ензиматичних систем у базолатеральній мембрані ентероцитів плодів великої рогатої худоби у меншій мірі залежить від морфометричних показників порожньої кишки, ніж така в апікальній мембрані. Так, лише активність лужної фосфатази та $\gamma$ глутамілтрансферази обернено пов'язана з товщиною кишкової стінки з ворсинками та слизової оболонки порожньої кишки з ворсинками ( $\mathrm{r}=-0,82-0,98$; $\mathrm{P} \leq 0,01-0,001)$. Тоді, як активність транспортних ензимів має прямі зв'язки з морфометричними показниками порожньої кишки $\left(\mathrm{Na}^{+}, \mathrm{K}^{+}\right.$-АТФази $-\mathrm{r}=0,74$, $\mathrm{P} \leq 0,05, \mathrm{Mg}^{2+}$-АТФаза $\left.-\mathrm{r}=0,84, \mathrm{P} \leq 0,01\right)$. Отже, від $55 \%$ до $96 \%(\mathrm{P} \leq 0,05-0,001)$ варіацій активності вищезгаданих ензимів на базолатеральному домені плазмолеми ентероцитів залежить від товщини кишкової стінки з ворсинками та слизової оболонки порожньої кишки з ворсинками плодів великої рогатої худоби.

Як і в апікальній мембрані, активність вказаних ензимів у базолатеральній мембрані достовірно не залежить від ширини самих ворсинок, однак є залежною від їх висоти. Так, кореляційний зв'язок активності лужної фосфатази і $\gamma$-глутамілтрансферази в апікальній мембрані ентероцитів 3 висотою ворсинок становив $-\mathrm{r}=-0,90(\mathrm{P} \leq 0,01)$ та $\mathrm{r}=-0,86(\mathrm{P} \leq 0,01)$, відповідно, від $74 \%$ до $81 \%(\mathrm{P} \leq 0,01)$ варіацій активності цих ензимів на базолатеральному домені плазмолеми ентероцитів залежить від висоти ворсинок порожньої кишки плодів великої рогатої худоби.

\section{Висновки}

Доведено залежність активності окремих ензимів на різних полюсах плазмолеми ентероцитів від морфометричних показників порожньої кишки плодів великої рогатої худоби. Отримані дані щодо мембранозв'язаних АТФаз та гідролаз ентероцитів у плодів великої рогатої худоби дозволяють сформувати відповідну уяву про фізіолого-біохімічну специфіку пренатального формування пристінкового травлення та всмоктування.

Перспективи подальших досліджень. 3 огляду на отримані результати перспективним $є$ дослідження особливостей процесів мембранного гідролізу, транспорту, секреції речовин у кишковому каналі жуйних тварин у пренатальному онтогенезі.

\section{References}

Boldyrev, A. P. (1977). Transportnyye adenozintrifosfatazy. Sovremennyye metody issledovaniya. Moskva: Izd-vo MGU (in Russian).

Guilloteau, P., Corring, T., Toullec, R., \& Robelin, J. (1984). Enzyme potentialities of the abomasum and pancreas of the calf. I.-Effect of age in the preruminant. Reproduction, nutrition, developpement, 24(3), 315-325. doi: 10.1051/rnd:19840310.

Johnston, D., \& Sanson, B. (2011). Epithelial polarity and morphogenesis. Current opinion in cell biology, 23(5), 540-546. doi: 10.1016/j.ceb.2011.07.005.

Kenny, A. J., \& Maroux, S. (1982). Topology of microvillar membrance hydrolases of kidney and intestine. Physiological reviews, 62(1), 91-128. doi: 10.1152/physrev.1982.62.1.91.

Lisowska-Myjak, B., Skarżyńska, E., \& ŻytyńskaDaniluk, J. (2018). Calprotectin in Serially Collected Meconium Portions as a Biomarker for Intrauterine Fetal Environment. Fetal diagnosis and therapy, 43(1), 68-71. doi: 10.1159/000472150.

Masiuk, D. M. (2020). The protein ratio at different poles of the enterocytes' cell membrane of the jejunum during the fetal stage in cattle. Theoretical and Applied Veterinary Medicine, 8(1), 62-68. doi: 10.32819/2020.81010.

Masiuk, D. (2020). Expression of plasmolemma proteins of the absorptive enterocytes of the cattle in the late fetal period. Ukrainian Journal of Veterinary and Agricultural Sciences, 3(1), 52-57. doi: 10.32718/ujvas3-1.10.

Studentsov, A. P.. Shipilov, V. S., Preobrazhenskiy, O. N. i dr. (2000). Beremennost. Veterinarnoye akusherstvo. ginekologiya i biotekhnika razmnozheniya. Moskva: Kolos (in Russian).

Tomchuk, V. A., Usatiuk, P. V., Tsvilikhovskyi, M. I., \& Melnychuk, D. O. (1994). Otrymannia izolovanykh klityn epite-liiu tonkoho kyshechnyka velykoi rohatoi khudoby. Fiziolohichnyi zhurnal, 40(5/6), 45-51 (in Ukrainian). 
Tsvilikhovskiy, N. I. (1989). Vydeleniye apikalnoy i bazolateralnoy membran enterotsita tonkoy kishki krupnogo rogatogo skota i strukturno-funktsionalnyye izmeneniya $\mathrm{v}$ nikh pri patologi. Fiziolohichnyi zhurnal, 35(5), 121 (in Russian).

Woods, L., Perez-Garcia, V., \& Hemberger, M. (2018). Regulation of Placental Development and Its Impact on Fetal Growth-New Insights From Mouse Models.
Frontiers in endocrinology, 9, 570. doi: $10.3389 /$ fendo.2018.00570.

Zhang, H., Fan, Y., Elsabagh, M., Guo, S., Wang, M., \& Jiang, H. (2020). Dietary Supplementation of LArginine and N-Carbamylglutamate Attenuated the Hepatic Inflammatory Response and Apoptosis in Suckling Lambs with Intrauterine Growth Retardation. Mediators of inflammation, 2020, 2453537. doi: $10.1155 / 2020 / 2453537$. 